\title{
The Russian Wheat Deal-Hindsight vs. Foresight
}

\author{
by CLIFTON B. LUTTRELL
}

\section{1}

N JULY and August 1972, the United States sold to the Soviet Union about 440 million bushels of wheat for approximately $\$ 700$ million, more than the total U.S. commercial wheat exports for the year beginning in July 1971. The sales were equivalent to 30 percent of average annual U.S. wheat production during the previous five years and more than 80 percent of the wheat used for domestic food during that period. The sales involved a series of subsidized transactions following an agreement whereby the U.S. Government made available credit of $\$ 750$ million to Russia for the purchase of grains over a three-year period. ${ }^{1}$ Previously, the Russians had purchased only a relatively small quantity of U.S. farm products.

Immediately following the sales announcements, the domestic price of wheat began to rise, and within a few months the prices of feed and food grain, soybeans, and livestock turned upward and all continued to rise at a high rate during most of the next twelve months (Chart I). By year-end food prices had also turned sharply upward. The price of wheat almost tripled during the year ending in August 1973. The prices of corn and soybeans more than doubled, and the prices of steers, hogs, and broilers rose 55,102 , and 153 percent, respectively (Table I). The wholesale price index of all farm products rose 66 percent, and the wholesale price of food increased 29 percent."

IOnly $\$ 500$ million of this credit could be outstanding at one time.

2U.S. Department of Labor, "Wholesale Price Index" (September 1973).

Page 2

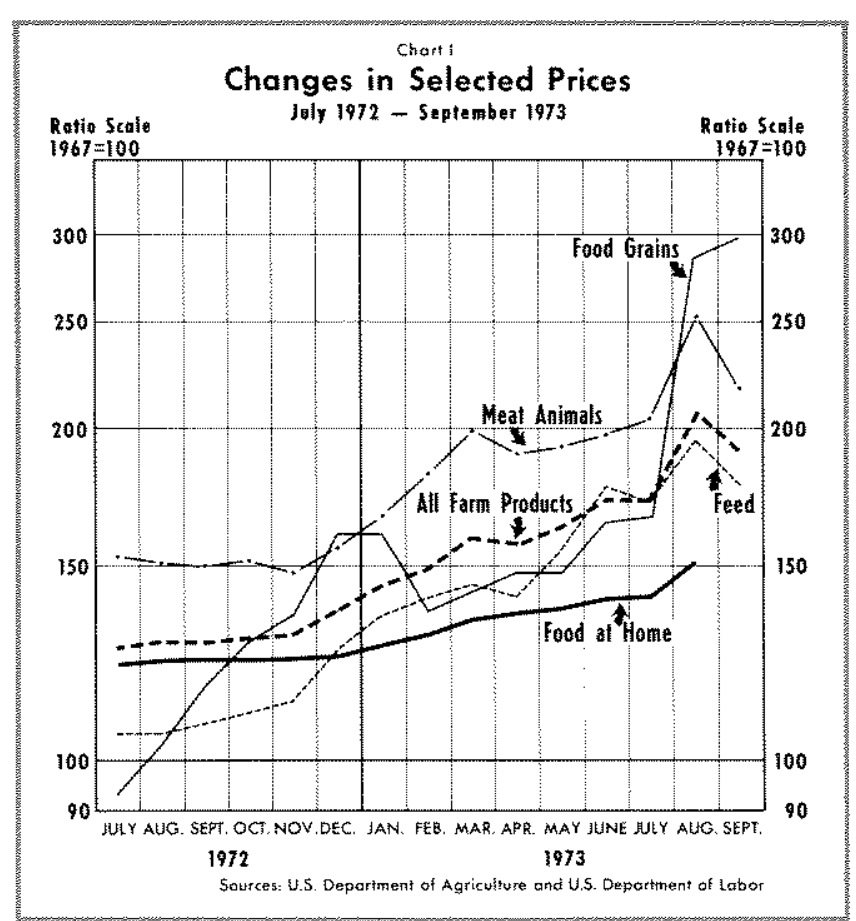

In recent weeks most of these farm commodity prices have declined somewhat from the mid-August 1973 levels, but retail food prices have generally continued upward.

A number of critics have attributed these sharp price increases to the Russian wheat transactions. The General Accounting Office ( $\mathrm{GAO}$ ), in a review of the sales, questioned the United States Department of Agriculture's (USDA) management of the wheat export subsidy program. The GAO concluded that the

\section{Page 2}




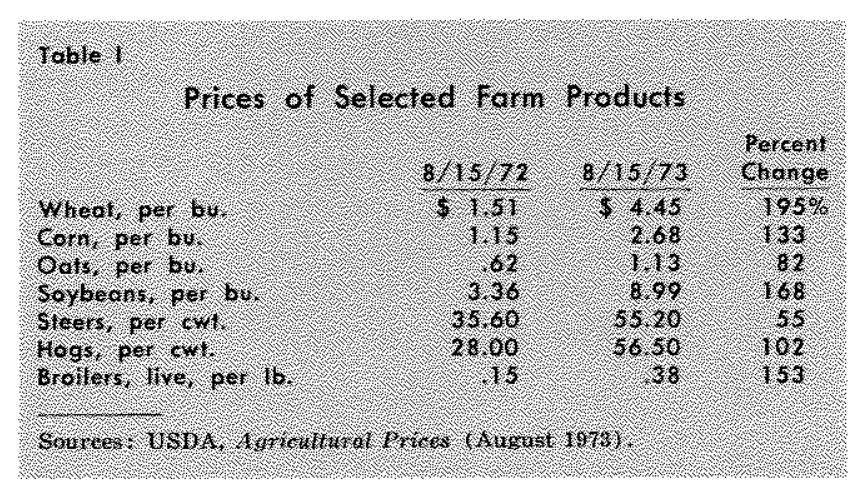

export subsidies were excessive and that the sales caused a dramatic rise in the price of wheat and higher consumer prices for bread and most livestock products. The press, in addition to attributing higher food prices to the subsidized sales, referred to the transactions in such terms as "the great grain robbery," "reaping the grain harvest," and "chaff in the great grain deal."

The questions raised by the critics involve both managerial problems and basic economic issues. While the accounting and auditing problems raised may be important and require additional rules and procedures for operating the program, this article deals only with those questions which relate to basic economic issues.

The position taken by the USDA on these issues was based on the established role of the Federal Government in dealing with farmers and farm commodities during most of the period since the mid-1930s. This article reviews the role of the USDA in controlling farm production, supporting farm prices, and subsidizing exports during this period. The Russian transactions are discussed in this context, and then some questions regarding the basic economic policies which were followed are analyzed.

\section{Summary of Critical Comments}

The GAO conclusions, following a review of the Russian transactions, include the following critical elements:

(1) The USDA maintained a low target price for wheat for several weeks after the sales began, obligating the U.S. Government to pay excessive subsidies to

\footnotetext{
aThe Comptroller General of the United States, Report to the Congress, Russian Wheat Sales and Weaknesses in Agriculture's Management of Wheat Expont Stabsidy Program (July 1973 ), pp. 2 and 25; Martha Hamilton. The Great American Grain Robbery and Other Stories (Washington: Agribusiness Accountability Project, 1972): Jack Anderson, "How Soviets Pulled the Great Grain Robbery" and "Reaping the Grain Harvest," St. Louis Globe Democrat, July 31 and August 21 , 1973, respectively; and "Chaff in the Great Grain Deal," Time magazine, August $6,1973$.
}

the private grain exporters. The USDA is committed to pay over $\$ 300$ million in subsidies on the Russian and other export sales. The GAO believes that many of these sales could have been made with smaller subsidies.

(2) Trading rules and procedures of the USDA are not adequate for dealing with the bargaining power of a foreign state trading monopoly. Such agencies are fully informed buyers and have an advantage when dealing with partially informed individual sellers.

(3) In 1967 the USDA granted to exporters the option of determining the date they register for subsidy payments. This action, as well as other features of the export program in effect at the time of the recent sales, tended to minimize risks and increase exporters' profits.

(4) Farmers were not provided with timely information with appropriate interpretative comments to help them make sound marketing decisions.

(5) The USDA has not comprehensively evaluated the wheat export subsidy program. Limited evaluations indicating that the subsidy program was not fully effective in reducing net export prices when the U.S. supply situation was scarce were dismissed by operating officials.

(6) The large volume of sales caused a dramatic rise in the price of U.S. wheat and higher consumer prices for bread, other flour-based products, beef, pork, poultry, eggs, and dairy products. ${ }^{5}$

The GAO made a number of recommendations as a result of its study. Among the recommended actions is a review of the wheat export subsidy program in its entirety including: a meaningful justification for the

The key determinant of the subsidy rate was the intemational target price - the price that the USDA attempted to maintain for U.S. wheat sold in foreign markets. Subsidies paid by the Govermment to exporters kept the target or international price for U.S. wheat at less than the domestic price. The subsidies were the difference between the domestic and target prices.

The wheat export subsidy programs began in 1949 as a result of U.S. obligations under the International Wheat Agreement. At that time, 42 nations agreed to trade a specified amount of wheat, under a negotiated schedule of minimum and maximum prices. Since the negotiated prices were lower than U.S. support prices to domestic wheat farmers, the exports required heavy subsidies. During the first four years of the program subsidies averaged about 62 cents per bushel and required a Government input of $\$ 546$ million. Before its suspension in late 1972 , the program had incurred a total subsidy cost of about $\$ 4.3$ billion for the export of about 10.5 billion bushels of wheat.

${ }^{5}$ Comptroller General, Russian Wheat Sales, pp. 24霍, 25, 55, and 56 . 
program's existence; a better system of coordinating sales of agricultural commodities to countries with nonmaket economies such as the USSR; a review of the legality of subsidy payments on sales to foreign affiliates of domestic exporting companies; the creation of a Govermment-farmer-industry committee to provide information on foreign agricultural needs; and a number of safeguards to assure that the amount of the subsidies is maintained at a reasonable level if a program review concludes that the subsidies are needed.

Based largely on the GAO findings, the press published statements to the effect that the subsidies were wasteful. It was reported that the grain exporting companies reaped large Federal subsidy payments at the same time they were making windfall profits from the export sales, and the transactions drained the United States of wheat supplies, contributing to sharply rising food prices. "Time magazine, for example, stated, "Consumers have a particularly good reason for anger: the deal contributed to a grain shortage in the U.S., driving up prices for bread, meat, poultry, and dairy products." These comments suggest the following questions:

(1) Were the price increases experienced since the Russian sales anticipated at the time of the sales?

(2) Did it appear likely at that time that the quantity of wheat purchased by the Russians could be delivered out of surplus stock?

(3) Were the Russian sales at subsidized prices consistent with the role assumed by the USDA during the past two decades?

(4) Were the farm product and food price increases a result of the sales?

\section{Only Modorate Price Thoreases Anthomater}

There are few who question the charge of the GAO and the press that the subsidized wheat sales to Russia reduced domestic wheat and feed supplies and contributed to the higher food prices. Wheat can be used for either food or livestock feed; thus, domestic food and feed prices would not have risen as much as they did had the subsidized sales not been made and had the wheat been released for domestic use.

Only moderate price increases, however, were expected at the time of the sales. For example, on August 15, 1972, six weeks after the three-year grain sales agreement with Russia was announced and four

"Anderson, "Reaping the Grain Harvest," August 21.

${ }^{7}$ Time nagazine, pp. 63 and 64. weeks after the first Commodity Credit Corporation credit sales were registered with the USDA, the futures price for May 1973 wheat at Chicago closed at

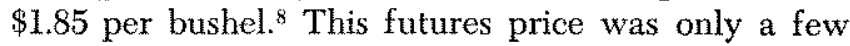
cents per bushel above the cash price for wheat on August 15. By May 1973, however, the cash price had risen to $\$ 2.71$ per bushel - $\$ 0.86$ per bushel more than the market had anticipated nine months earlier.

On August 15, 1972, the futures price for corn to be delivered in May 1973 was about $\$ 0.25$ per bushel less than the subsequent actual cash price in May 1973, and a futures contract for May 1973 soybeans sold for about one-half of the actual cash price for soybeans in May. Futures prices of eggs, cattle, and hogs were likewise well below actual cash prices on the delivery dates.

As late as September 15, 1972, only a week before the wheat export subsidy was removed, futures prices for 1973 delivery reflected only moderate domestic price increases for feed and livestock. In September 1972, wheat futures for May 1973 delivery sold for $\$ 2.18$ per bushel, corn for $\$ 1.51$, and soybeans for $\$ 3.53$, somewhat above the September 1972 cash prices, but well below the cash prices of $\$ 2.81, \$ 1.61$, and $\$ 8.27$ for wheat, corn, and soybeans, respectively, on the delivery dates. ${ }^{4}$

Market participants, as indicated by the futures prices, recognized that the Russian purchases would tend to increase prices. Hence, no confusion existed as to the direction of price movements. The amounts of the increases, however, are only clear from "hindsight." The price increases and the causal forces were readily observed as they unfolded, but at the time of the sales a number of factors which later affected prices could not be observed.

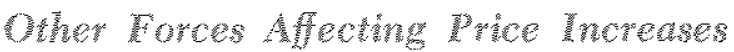

In September 1972, few observable indicators pointed to the short world supply of key farm products and the sharp price increases that subsequently occurred. No widely distributed forecast indicated price increases of 140 percent for wheat, 165 percent for

\footnotetext{
The "futures price" is the price of current contracts for future deliveries of commodities. For example, the price of $\$ 8.62$ per bushel agreed upon now but to be paid upon receipt of soybeans in May 1974 is called the May futures price. For a more complete discussion of futures prices and functions of futures markets, see Armen A. Alchian and William R. Alen, University Economics, 3ro ed. (Belmont, California: Wadsworth Publishing Company, Inc, 1972), pp. 163-67.

a Cash prices used are average prices received by famers as reported by the USDA, Agricultural Prices. Futures prices are prices as reported by the Wall Street Jourmal.
} 
corn, and 210 percent for soybeans by August 1973. The 40 percent annual rate of increase in the consumer price index for meat, poultry, and fish during the first six months of this year was likewise unforeseen.

Important supply and demand factors, other than the wheat sales, which contributed to the price increases became apparent following the wheat sales. The sharp cutback in output of Peruvian fish meal, a major source of protein for animal feed, was an important supply-reducing factor in the rising feed and livestock prices. A decline in production of wheat, rice, corn, and peantuts in other parts of the world as a result of unfavorable weather caused a sharp increase in the export demand for U.S. wheat, feed grains, and soybeans. Here in the United States, output of beef and pork rose less than expected because farmers were adding heifers to their beef herds, and a number of farmers had dropped their hog enterprises after experiencing heavy losses in 1971. A realignment of world currency values permitted greater farm commodity purchases from the United States with a given amount of foreign currency. In addition, the high rate of U.S. monetary growth and the unfavorable U.S. harvesting season in the fall of 1972 were important forces tending to increase farm product and food prices early this year.

The observed price increases reflected the impact of all these largely unpredictable factors converging at one time. Also, in view of the nation's extended experience with excess supplies, neither the outlook specialists nor the futures markets were able to predict the sharp price increases that actually occurred.

In July and August 1972 a downturn in Soviet wheat production was indicated. Also, the Soviets had stated that they wanted to increase meat production. However, as pointed out by the Secretary of Agriculture, their buying intentions were not made known. ${ }^{10}$

At the time of the sales, there was no certainty about the volume of wheat exports, since it was very late in the season before the Soviet wheat purchase intentions became apparent. ${ }^{11}$ Thus, given the export subsidy program's objective of reducing farm surpluses, the GAO view, that much of the $\$ 300$ million obligated for export subsidies was unnecessary to achieve the sales, may be based largely on supply and demand factors which unfolded subsequent to the transactions, or with the benefit of "hindsight" analysis.

${ }^{10}$ Comptroller General, Russian Wheat Sales, p. 70. 11 Ibid.

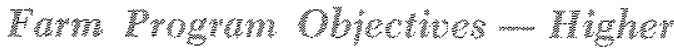

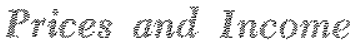

Increases in farm and food prices following the sales to Russia are not sufficient reasons for criticizing the USDA. As the Secretary of Agriculture pointed out, "Such programs exist only to protect U.S. farmers from having to accept low world prices for a few farm commodities which depend heavily on exports and must meet subsidized export competition."12

Numerous public statements and congressional declarations imply that the Government farm programs are designed to achieve higher farm prices and farm incomes than are attainable in a free market setting. ${ }^{13}$ These programs have taken several forms including programs to increase the demand for and reduce the supply of U.S. farm products. They include programs to increase the utilization of farm products, such as the domestic food and farm commodity export subsidies; programs to reduce farm production, such as acreage allotments, marketing quotas, and land retirement; programs of direct payments to farmers, such as the payments to wool, com, cotton, and wheat producers; and programs designed to differentiate markets for farm products, such as the two price plans for certain commodities, the Government marketing orders for fluid milk and other commodities, and the import quota program for sugar., ${ }^{14}$

Since 1961 about 50 million acres per year have been witheld from crop production under the various Government land retirement programs. This acreage withheld from crop production under the various Government farm programs was equal to about one-sixth of the average acreage planted to the 59 principal crops during the decade 1961-70 inclusive and only slightly less than one-sixth of the planted acreage during 1971 and 1972 (Table II).

Surpluses of farm commodities arose as a result of the Government price supports for certain basic crops. The Government guaranteed a fixed price to farmers through nonrecourse Commodity Credit Corporation loans on the harvested crops. As has been pointed out by Paarlberg, rather than learning to live with an abundance of farm commodities at market prices, the nation insisted on a policy of artificial scarcity by

\footnotetext{
12Ibid., pp. 69 and 70 .

13See Rainer Schickele, Agricultural Policy (New York: McGraw-Hill Book Company, Inc, 1954), p. 167, and Don Paariberg, American Farm Policy (New York: John Wiley and Sons, 1964), pp. 68-72.

14 For a more complete discussion of this topic, see Paatlberg, American Farm Policy, pp. 247-328.
} 


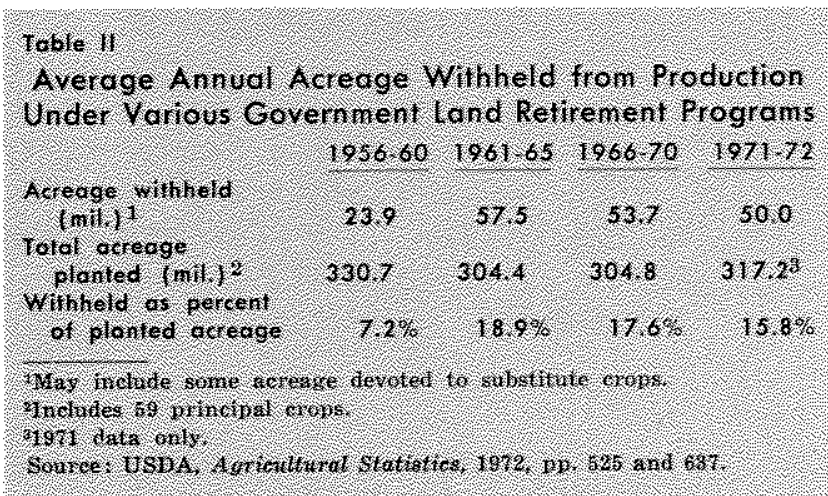

pricing farm commodities at higher than market levels throughout the late $1950 \mathrm{~s}$ and $1960 \mathrm{~s} .^{15}$

\section{Surpluses-A Legacy of Goverment Price Supporis}

A look at the record of the farm price support programs prior to September 1972 reveals a long record of excess supplies of farm products - a larger quantity produced than could be sold at the Government price support levels. As indicated in Table III, carryovers and surpluses of farm commodities were relatively small in the 1926-29 period, prior to the price support programs. The "excessive" carryover stocks only developed following the Government price supports. For more than two decades, the USDA has administered a system of farm price supports that maintains farm product and food prices above free market levels. The

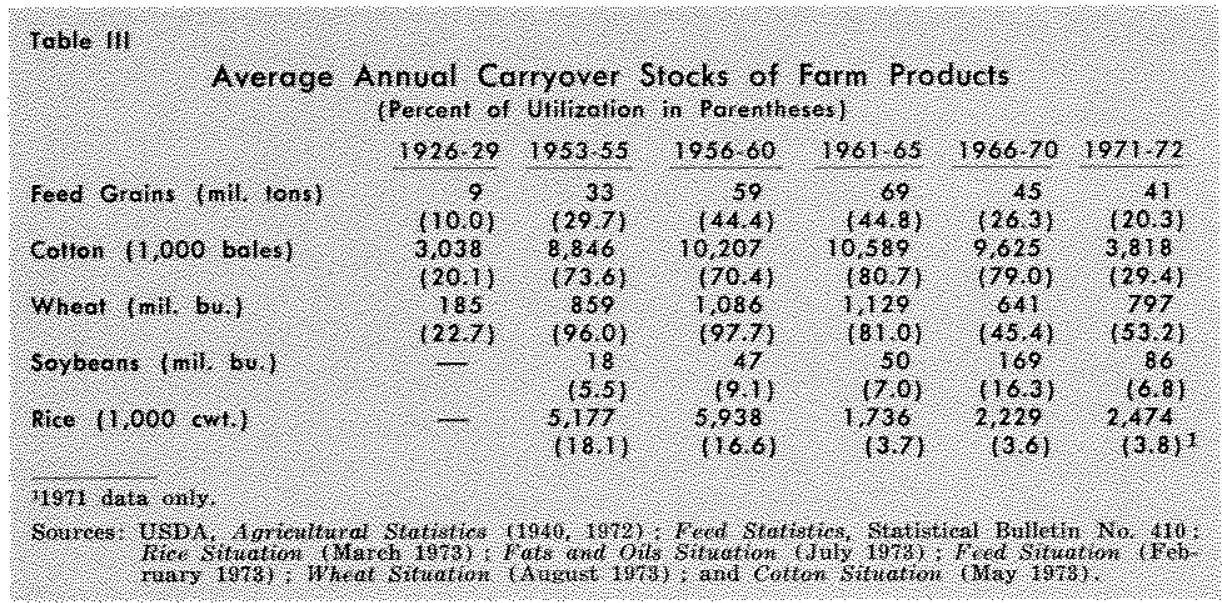

Carryover stocks of wheat into the subsequent marketing year have often exceeded annual utilization (amount used for both domestic and export purposes). Such surplus stocks, largely held by the Government, exceeded total utilization in six of the twenty years from 1953 to 1972 inclusive, and for the entire twenty-year period carryover stocks averaged 75 percent of utilization. During the five years from 1956 through 1960, carryover stocks averaged 98 percent of annual utilization (Table III). Beginning in 1964, the wheat surplus stocks were reduced somewhat as a result of a new program which provided for direct Government payments to producers and lower support prices. Since then, carryover stocks have averaged only about 50 percent of annual utilization. Carryover stocks of all feed grain (corn, oats, barley, and grain sorghum) exceeded 40 percent of total utilization in eight of the past twenty years and averaged 37 percent of annual use for the entire period from 1953 to 1972. Surplus stocks of cotton were also a major problem until the past two years, averaging 80 percent of annual utilization from 1961 to 1970 .

The major portion of the large carryover stocks of recent years was held in storage by the USDA at the taxpayers' expense. Hence, since the early 1950s, a major problem of the Government farm programs, given the level of support prices, has been the disposal of accumulated surpluses. In fact, much has been said about the "great farm-surplus" problem - the Government's holdings of a slowly deteriorating surplus product.

\section{Peduction of Supluses Apperenty Benefind}

In view of the overall farm program costs, any returns that could be realized from the surplus product appeared to be cost-reducing. Total USDA outlays for all purposes during the period 1967-72 inclusive exceeded $\$ 49$ billion, or 4.2 percent of total Federal Government expenditures (Table IV). The anmual outlays rose from $\$ 5.8$ billion in 1967 to $\$ 10.9$ billion in 1972 , or from 3.7 to 4.7 percent of total Federal Government expenditures.

Those expenditures directly associated with efforts to increase farm incomes, such as outlays for commodity price supports, acreage retirement, income payments, and export subsidies (farm income stabilization and Food for Peace), totaled $\$ 33.1$ billion, or

15Paarlberg, American Farm Policy, p. 341. 


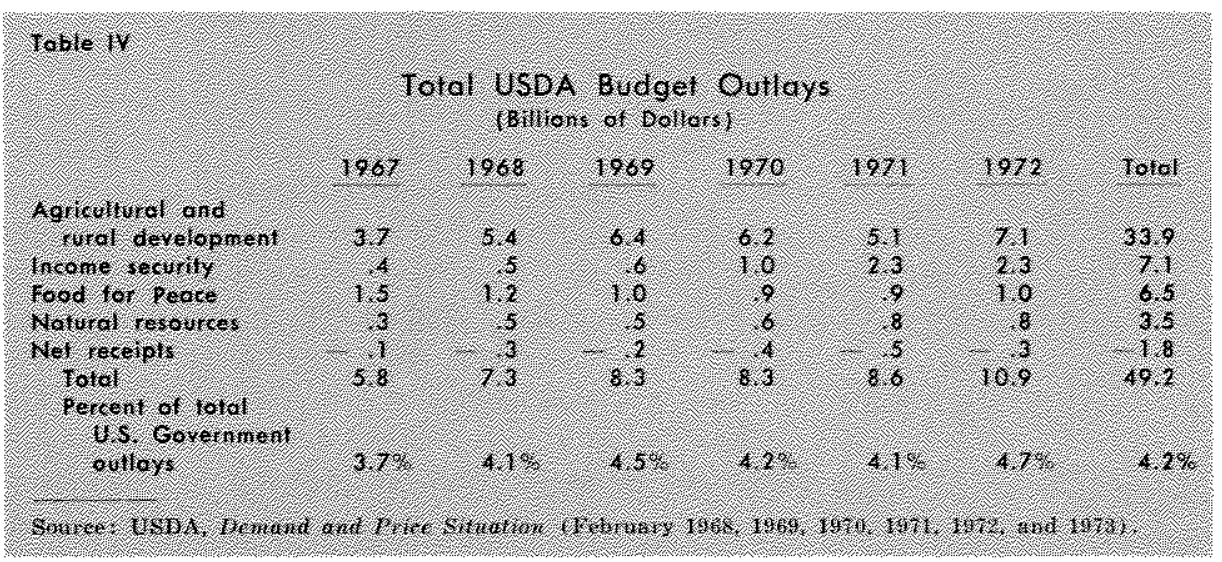

two years, $1970-71$ and 1971 72 , and 1,426 million bushels during the previous five years (Table VI, p. 8). The supply thus appeared adequate to meet all foreseeable demands at the support price level.

The USDA view that the Russian transactions resulted in a net saving to the Treasury of $\$ 457$ million $^{16}$ is thus consistent with the farm program objectives during a two decade

about two-thirds of total USDA expenditures during the six-year period. In addition, USDA outlays for income security, consisting largely of food stamps (intended in part to enhance domestic demand for farm products), totaled $\$ 7.1$ billion. All these expenditures have been equivalent to about one-third of the net farm income since 1956 (Table V). Such expenditures have increased somewhat in recent years, but have declined relative to total farm income since 1966 . With these sizable outlays to increase farm product prices and farm incomes, an easy bargaining stance with the Russians to eliminate the wheat surpluses appeared to be a cost-reducing policy.

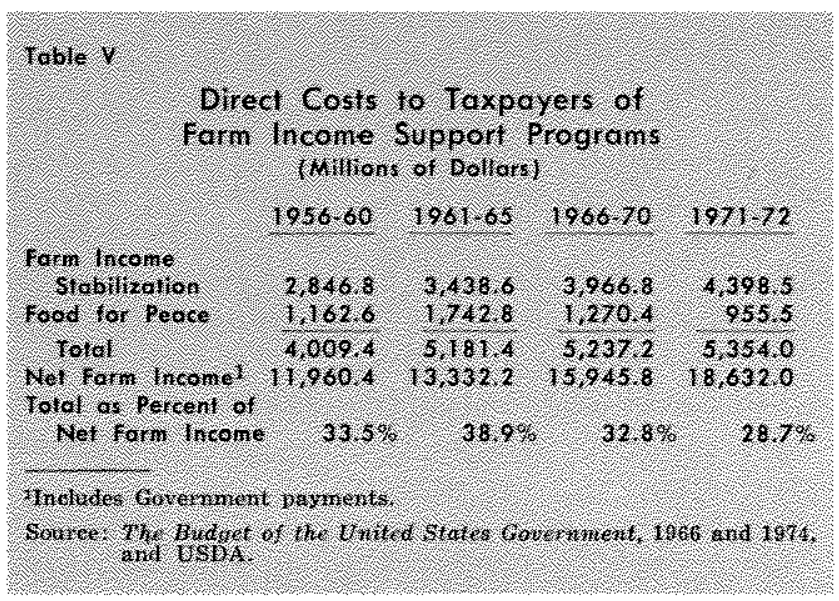

\section{Wheren Subsides Consistent Wuth she Systerts}

On the basis of the evidence available at the time of the transactions, the subsidies paid to wheat exporters in 1972 appear to be consistent with past practice. Wheat stocks carried over into the 1972-73 marketing year totaled 865 million bushels, which, added to the 1972 estimated production of 1,551 million bushels, resulted in total estimated supplies of 2,417 million bushels. Utilization (domestic use plus exports) averaged only 1,516 million bushels in the history of excessive wheat stocks. Such stocks were often viewed as liabilities rather than assets. ${ }^{17}$ Hence, given the basic farm program system which was designed to channel more income to farmers, the USDA acclaimed the transactions as beneficial by (1) increasing the prices that farmers receive for their crops, (2) creating new jobs, and (3) improving the balance of trade. ${ }^{18}$

\section{Wastc Problam - A Fanty System}

The basic objectives of the Government farm programs come into focus in an economic analysis of the Russian wheat sales. The critics' view that the subsidized transactions led to higher food prices and reduced the well-being of U.S. consumers is in direct opposition to the USDA view that the sales were beneficial. Under the producer-oriented farm programs, the sales served to enhance farm incomes, thereby achieving the programs' major objective. Neither the critics nor the USDA, however, seriously suggested that the programs may not be compatible with the economic well-being of the nation. Some recognition of a basic problem was apparent in the GAO's comment on "Matters for Consideration by the Congress:"

U.S. agriculture's productive capacity has traditionally resulted in surplus stocks which were stored at great expense or exported with subsidy. Although exports are important to achieving U.S. trade objectives, they can have an adverse effect. Recent dramatic changes in the world supply-demand situation surfaced a need for assessing agricultural exports in a broader national context. Congress should consider requiring that agencies develop definitive ground rules so that expected benefits from exports can be appropriately weighed against their impact on various segments of the domestic economy. ${ }^{10}$

16 Comptroller General, Russian Wheat Sales, p. 2

17Paarlberg, American Farm Policy, p. 56.

18 Comptroller General, Russian Wheat Sales, p. 2.

19 Ibid., p. 5. 


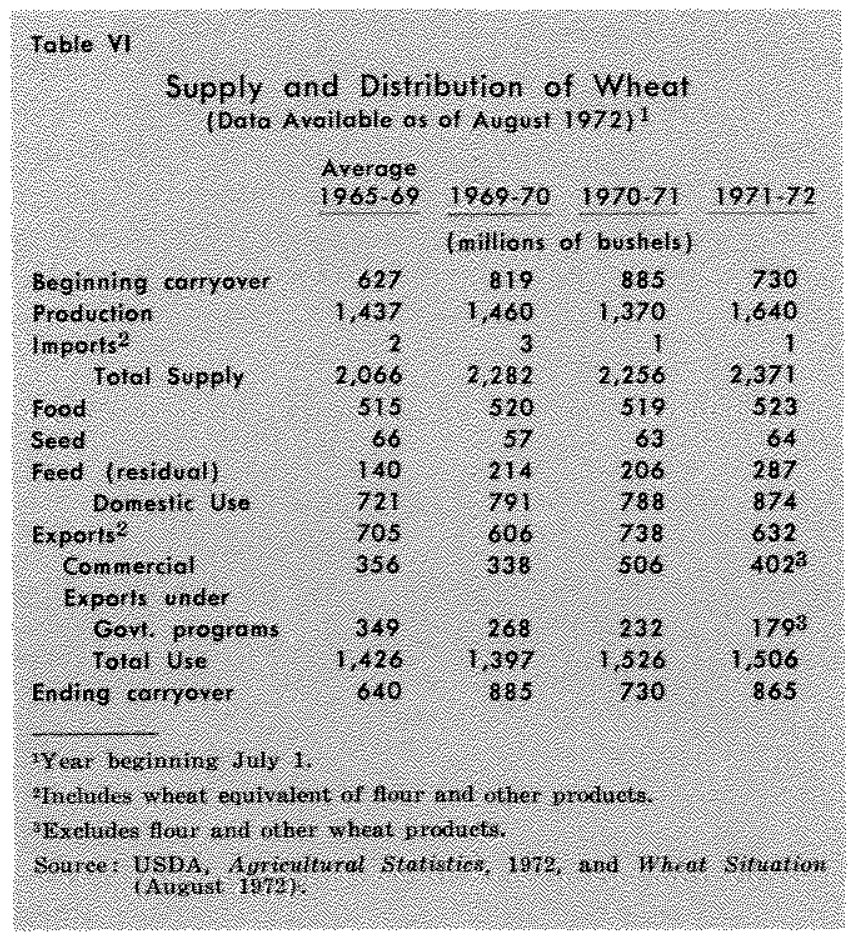

This statement, that the use of subsidies to reduce surplus stocks of farm commodities can have an adverse domestic effect, indicates recognition that the practices reviewed should be changed. The implied solution, however, is better ground rules for the administration of the programs rather than a thorough economic analysis of the issues raised. The basic economic questions involved were not approached in the discussion of the transactions. For example, are producer-oriented price and income support programs consistent with the maximum well-being of all the people? Given that artificially high price supports to producers tend to encourage production above market-clearing levels, will the entire output be sold in the absence of export subsidies?

The price system is the mechanism that brings into equality the production and consumption of farm products at an optimum level in a competitive economy without Government interference. Farming is highly competitive. It meets the major competitive tests of a large number of producers with easy entry and easy exit. No single producer can have an important effect on the output or price of farm products. When consumers desire more farm products, they will bid up the price and the higher price will attract additional resources into agriculture. Conversely, when demand for farm products falls, prices of farm products will decline and resources used in agriculture will be attracted to other industries where the returns are more favorable.
Price supports for farm products at higher than market-clearing levels, or other methods designed to enhance farm incomes above levels determined by free market prices, alter the normal relationships between resources used in production and consumption. Both high support prices and farm income supplements attract excessive resources into agriculture from alternative uses. High support prices alone provide the incentive to produce more farm commodities than will clear the market at the support price level. Furthermore, all the methods of farm income support reduce the economic well-being of the nonfarm sector of the economy, and are of doubtful long-run benefit to farm workers. Hence, it is not only the expected benefits from exports that should be weighed against their unfavorable impact on various segments of the domestic economy; rather, it is all losses from reduced nonfarm output, higher food prices, and higher tax payments to finance the farm programs that must be weighed against the probability of enhanced incomes to individual farm workers. Since returns to labor and other resources tend toward equality in a competitive economy, any gains occurring to farm workers through price or income supports are likely to be of short duration unless a monopoly position can be maintained through control of entry.

\section{The Ners Tam int}

Some unfavorable impacts of the farm programs on the well-being of most people were apparently recog nized in the four-year farm bill passed by Congress in August of this year. Most crop production restrictions have been removed, and income and price support payments are likely to be less than in recent years. Wheat farmers are not required to abide by conservation reserves, and there is no conserving base or setaside acreage requirement for grain or cotton plantings.

Crop allotments remain intact for most basic crops but are only a means for determining the acreage on which supplemental payments will be made in case the market price drops below the target price. Current market prices for most farm products are well above "target" prices which would trigger off the payments. Target prices are set for 1974 at $\$ 2.05$ per bushel for wheat, $\$ 1.38$ per bushel for corn, $\$ 2.34$ per cwt. for milo, $\$ 1.13$ per bushel for barley, and $\$ 0.38$ per pound for cotton.

While it is difficult to estimate the cost of the program in terms of direct Treasury disbursements, most analysts believe that it will be well below farm pro- 
gram costs of recent years. Furthermore, the less restrictive farm program coupled with the lower supplemental payments in prospect should enhance the wellbeing of farmers, other taxpayers, and consumers.

\section{Summary and Conclusions}

In summation, the recent sharp increase in food prices has brought the 1972 Russian wheat sales and the wheat export subsidy program to the attention of the public. The discussion in the press has centered partly around the administrative details of the transactions, but some basic economic issues have been involved in the debate. The use of subsidies to export wheat has been questioned, since such exports tend to reduce the domestic grain supply and increase prices of food used at home.

The wheat surpluses, which were exported, accrued as the result of a national policy of maintaining high price supports to wheat producers. Similar export subsidies had been used by the USDA for more than two decades to reduce surplus stocks, and the recent subsidies were generally consistent with accepted practice. The objective of the farm programs was higher farm prices and incomes. Prices rose following the Russian sales, but the extent of the increases was not anticipated because of a series of other factors, all of which tended to increase farm product prices.
The critics accused the USDA of contributing to higher food costs by subsidizing the sales. The sales no doubt tended to increase farm product and food prices, but the USDA cannot be faulted on this charge. Most of the Government farm programs in effect during the past two decades were designed to increase farm product prices even though higher food prices were a consequence of the programs. Thus, from the USDA's view, the sales were beneficial since they contributed to higher farm prices and incomes.

Furthermore, there have been few critics of these USDA actions - actions which have caused artificially higher prices in the past. Even critics of the Russian wheat sales did not discuss the underlying problem. They complained primarily of faulty USDA operations, whereas the real culprit was a faulty system of farm income and price support programs. These prow grams contribute to higher food prices and are wasteful of scarce resources. They provide incentive for the use of more resources in agriculture than is consistent with a level of output that can be sold at market prices. They are of doubtful benefit to farm workers and tend to reduce the output of nonfarm goods and services and the well-being of most segments of the population.

This article is available as Reprint No. 81 .

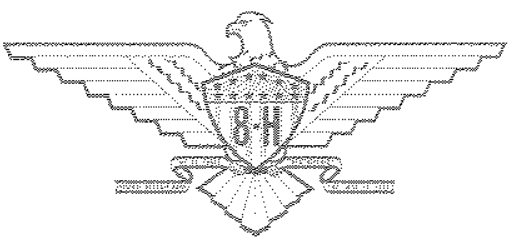

